\title{
LITIGASI HYBRID CONTRACT GADAI PADA LEMBAGA KEUANGAN SYARIAH
}

\author{
Sirajul Arifin \\ Universitas Islam Negeri Sunan Ampel Surabaya, Indonesia \\ E-mail: sirajul.arifin@uinsby.ac.id
}

\begin{abstract}
The article examines the hybrid contract that is still debated although the contract has framed pawn products in Islamic financial institutions. The pawn system which has been regulated by the DSN-MUI, however, still leaves a problem. The problem arises because the mortgage system is a combination system of several contracts that require collateral. Collateral is used to build bank trust and the customer's responsibility that the customer will return the loan in accordance with the contract. The used contracts are the loan, mortgage and lease agreements. If the financing in the mortgage system is default, the collateral item becomes the compensation for the repayment of the remaining debt of the customer. Pawn systems that require sublimation of several contracts in pawn products still become a subject of criticism. Hadiths about the prohibition of bay ${ }^{6}$ and salaf, prohibitions requiring additional debt, and the prohibition of charging fees for collateral are those that criticize and are not aware of pawn hybrid contract. Even though the pawn hybrid contract is still criticized, the demand for contemporary transactions in sharia financial institutions cannot be ignored, even its presence is a necessity as long as it does not violate sharia norms and values.
\end{abstract}

Keywords: Hybrid contract; mortgage system; syaria financial institutions; fiqh.

\section{Pendahuluan}

Bunga yang menjadi instrumen untuk mendapatkan keuntungan pada lembaga keuangan telah disepakati mayoritas ulama sebagai intrumen ribawi. Kesepakatan mereka meniscayakaan instrumen pengganti yang steril dari unsur ribawi. Akad muamalah adalah instrumen akad pengganti dalam memperoleh keuntungan pada lembaga keuangan syariah. Akad ini pun mengalami transformasi dalam memenuhi kebutuhan transaksi. Transformasi akad 
muamalah-yang semula personal menjadi institusional karena diadopsi dan diadaptasi oleh lembaga keuangan syariahmenimbulkan kesulitan bagi praktisi lembaga keuangan syariah.

Kesulitan tersebut semakin terasa di era transaksi keuangan modern yang semakin kompleks karena membutuhkan desain kontrak yang tidak hanya dalam bentuk akad tunggal tetapi juga dalam bentuk kombinasi beberapa akad. ${ }^{1}$ Bentuk akad tunggal tidak mampu merespons transaksi keuangan kekinian yang selalu bergerak dan terpengaruh oleh industri keuangan baik nasional, regional maupun internasional. Karenanya, keberadaan kombinasi akad saat ini adalah sebuah keniscayaan. Keniscayaan kombinasi akad bagaimanapun tetap menyisakan persoalan.

Persoalan muncul karena realitas kombinasi akad dipandang tidak inline dengan berbagai literatur yang menjustifikasi bahwa syariah tidak membolehkan dua akad dalam satu transaksi akad (two-in-one). Padahal, larangan two-in-one dalam hadìth hanya mengenai tiga kasus yang berkaitan dengan larangan penggunaan bybrid contract, yaitu larangan bay'atān fì bay'ah, larangan safqatān fì safqah, dan larangan bay' dan salaf. ${ }^{2}$ Salah satu kasus bybrid contract ini terjadi pada akad gadai.

Gadai atau rahn adalah menahan salah satu harta milik si peminjam sebagai garansi pinjamannya. Praktik rahn semacam garansi utang $^{3}$ telah ada sejak zaman Rasulullah sebagaimana sabda-Nya dalam riwayat al-Bukhārī dan Muslim dari 'Āishah yang artinya "Sesungguhnya Rasulullah pernah membeli makanan dengan berutang

\footnotetext{
1 Nazīh Hammād, al-'Uqüd al-Murakkabah fì al-Figh al-Islāmì (Damaskus: Dār alQalam, 2005), 7. Kombinasi beberapa akad (bybrid contract) dikenal dengan istilah multiakad. Kata "multi" berarti "banyak; lebih dari satu, lebih dari dua; dan berlipat ganda". Lihat Tim Penyusun Kamus Pusat Bahasa Departemen Pendidikan Nasional, Kamus Besar Bahasa Indonesia, ed. 3 (Jakarta: Balai Pustaka, 2007), 761. Dengan demikian, multiakad berarti "akad ganda atau akad yang banyak, lebih dari satu" yang dalam literatur Arab disebut dengan al-uqüd al-murakekabah. Hammād mendefinisikan al-uqüd al-murakkabah sebagai konsesi para pihak untuk melakukan transaksi yang mengandung dua akad atau lebih. Kesepakatan yang dibangun atas akad ganda tentu memiliki implikasi hukum. Implikasi hukum dari akad-akad tersebut, serta hak dan kewajiban yang merupakan elemen integral adalah sama dengan akibat hukum dari satu akad. Lihat Ḥammād, al-Uqüd al-Murakekabah, 7.

2 Agustianto, Inovasi Produk Perbankan Syariah dari Aspek Pengembangan Fikib Muamalah (Jakarta: IAEI, t.th.), 2.

3 Abdul Gofur Anshory, Gadai Syariah di Indonesia: Konsep, Implementasi, dan Institusional (Yogyakarta: Gadjah Mada University Press, 2006), 88.
} 
dari seorang Yahudi, dan nabi menggadaikan sebuah baju besi kepadanya". ${ }^{4}$

Hadīth di atas secara tegas menggambarkan fungsi sosialkonsumtif bahwa gadai syariah hakikatnya bertujuan untuk memenuhi kebutuhan mendesak masyarakat menengah-bawah dan bukan untuk usaha komersial-produktif masyarakat menengah-atas. ${ }^{5}$ Motif gadai dalam realitas keuangan syariah, kini, tampak berubah dan tidak mencerminkan substansi hadìth di atas. Perubahan kecenderungan yang demikian bisa dicermati bagaimana Dewan Syariah Nasional Majelis Ulama Indonesia (DSN-MUI) mengonstruk aturan normatif yang mengatur soal gadai dalam lembaga keuangan syariah.

Dalam aturan DSN-MUI No. 26/DSN-MUI/III/2002 yang diperkuat dengan aturan DSN-MUI No. 92/DSN-MUI/IV/2014 terdapat tiga akad, yaitu akad gadai, akad hutang dan akad ijarah. Ketiga akad ini tidak selalu berjalan dan dijalankan secara terpisah, namun kerap berjalin kelindan ketika produk gadai dikonstruk dalam lembaga keuangan syariah. Jalinan akad model yang demikian dikenal dengan bybrid contract yang keabsahannya masih diperdebatkan. Perdebatan semakin mengemuka terutama ketika menilik kembali hadīth nabi tentang pemanfaatan utang (qard). Jika memandangnya melalui konteks pemanfaatan qard, maka praktik akad di atas dikatakan ribawi sebagaimana hadìth kull qard jarr manfa'ah fahuwa riban. ${ }^{6}$ Hadìth ini menggambarkan qard (hutang) tidak dapat dimanfaatkan untuk tujuan komersil dan mengambil keuntungan, sedangkan aturan DSN-MUI menyatakan keabsahannya dengan multiakad dalam akad gadai.

Kontradiksi dan gap antara dua hadìth dan dua aturan DSN-MUI dalam menyikapi bybrid contract, karenanya menggugah dan menuntut penulis untuk mengkaji dan meneliti dua masalah pokok, yaitu; "bagaiamana sistem gadai menurut aturan DSN-MUI No. 26/DSNMUI/III/2002 dan No. 92/DSN-MUI/IV/2014", dan "bagaimana aturan DSN-MUI yang merefleksikan bybrid contract dalam konteks litigasi fikih". Masalah pokok yang menjadi kegelisahan akademik didekati dengan pendekatan yang tepat, dan karenanya, pendekatan yang digunakan untuk memecahkan masalah penelitian ini adalah

\footnotetext{
${ }^{4}$ Abū 'Abd Allāh Muḥammad b. Ismāāl b. Ibrāhīm b. Mughirah b. Bardizbah b. alBukhārī al-Ju'fī, Saḥ̣̄̄ al-Bukhārì, Vol. 3 (Beirut: Dār al-Fikr, 1983), 18.

${ }_{5}^{5}$ Adrian Sutedi, Hukum Gadai Syariah (Bandung: Alfabeta, 2011), 32.

${ }^{6}$ Ibn Taymìyah, Majmū' Fatāwà Ibn Taymīyah (Kairo: Dār al-Hadīth, 1995), 94.
} 
pendekatan yuridis-normatif, yaitu suatu telaah kritis terhadap sistem gadai menurut aturan DSN-MUI No. 26/DSN-MUI/III/2002 dan aturan DSN-MUI No. 92/DSN-MUI/IV/2014 melalui litigasi fikih kekinian yang bersumber dari naṣs al-Qur'ān dan Hadīth serta pendapat ulama.

\section{Evolusi Konseptual Hybrid Contract}

Hybrid contract merupakan frasa yang di-setting bukan tanpa tujuan, melainkan bertujuan untuk menggambarkan beberapa akad dalam transaksi tertentu pada lembaga keuangan syariah. Ketika lembaga keuangan syariah mengalami kesulitan untuk memperoleh keuntungan dan produk tertentu tidak dapat dijalankan bila tidak menggunakan beberapa akad dalam satu transaksi, maka kehadiran akad bybrid merupakan suatu keniscayaan dan tidak dapat terhindari.

Keniscayaan bybrid contract dalam lembaga keuangan syariah yang masih menyisakan polemik tentang keabsahannya tidak menutup bahkan meniscayakaan terbukanya kran pandangan para ulama atau pakar untuk terus membincang soal akad muamalah dan evolusinya secara implementatif dalam dunia perbankan syariah. Konsepsi akad dan evolusinya dapat digambarkan dalam kajian berikut.

1. Konsep dan Evolusi Akad

Istilah "akad" (al-aqd/contract) banyak dikenal dengan istilah "perjanjian". Kata al-aqd (akad), yang berasal dari kata 'aqada-ya'qidu'aqdan, secara bahasa bermakna al-ribt (ikatan), al-shad (pengencangan), al-taqwiyah (penguatan). Jika kata al-'aqd digandeng dengan kata lain, misalnya 'aqada al-ḥabl (mengikat tali), maka kata tersebut memiliki makna mengikat tali satu dengan tali lain untuk memperkuat ikatannya. Kata al-'aqd tidak terbatas dan hanya memiliki satu makna tetapi juga memiliki makna lain, yaitu al'ahd (janji) atau al-mithāq (perjanjian). ${ }^{7}$

Kata 'aqada, pada awalnya, digunakan untuk menunjukkan benda padat seperti tali dan bangunan, namun kemudian kata ini berevolusi dan mengalami perluasan makna, 'aqd al-bay' (akad jual beli), 'aqd al'ahd (akad perjanjian), dan 'aqd al-nikāḥ (akad nikah). Perluasan makna yang demikian berimplikasi pada pemaknaan 'aqada sebagai ilzām (pengharusan), dan iltizàm (komitmen) atau irtibāt (pertautan). ${ }^{8}$

\footnotetext{
7 'Abd al-Ra'ūf al-Minawī, al-Tawqîf 'alà Mubimmāt al-Ta'arîf, ed. M. Riḍwān al-Dayah (Damaskus: Dār al-Fikr al-Mu'āṣir, 1410), 68.

${ }^{8}$ Ibid.
} 
Menurut al-Zarkasyi, makna al-'aqd-secara bahasa-mengalami transformasi shar'ì menjadi irtibät al-ijäb bi al-qabül (keterikatan ijab dengan kabul), seperti akad jual beli, akad nikah, dan akad lainnya.

Keterikatan al-'aqd, bagi para ahli fikih, adalah keterikatan bagianbagian tasarruf secara shari $i$ dengan ijab dan kabul; atau komitmen dua pihak yang berakad dan kesengajaan keduanya atas suatu perkara. Dengan demikian, al-'aqd merupakan ungkapan mengenai keterikatan ijab dan kabul (íbārah 'an irtibät al-ijāb wa al-qabü). Dalam kaitan ini, Bashā menjelaskan bahwa akad merupakan "pertemuan ijab yang diajukan oleh salah satu pihak dengan kabul dari pihak lain yang menimbulkan akibat hukum pada objek akad". 'Definisi Bashā, karenanya, dipandang Anwar sebagai definisi yang komprehensif karena akad merupakan pertemuan ijab dan kabul sebagai pernyataan kehendak dua pihak atau lebih untuk melahirkan suatu akibat hukum pada objeknya. ${ }^{10}$

Kedua definisi terakhir menunjukkan bahwa pertama, akad merupakan keterkaitan ijab dan kabul yang berakibat pada timbulnya akibat hukum, kedua, akad merupakan tindakan hukum dua pihak karena akad adalah pertemuan ijab yang merepresentasikan kehendak dari satu pihak dan kabul yang menyatakan kehendak pihak lain, dan ketiga, tujuan akad adalah melahirkan suatu akibat hukum. Tujuan akad dapat dikategorikan menjadi lima, yaitu; pemindahan milik dengan imbalan ataupun tanpa imbalan (al-tamlik), melakukan pekerjaan (al-'amal), melakukan persekutuan (al-ishtiräk), melakukan pendelegasian (al-tafwìd), dan melakukan penjaminan (al-tawthiq). Tujuan-tujuan akad, bagaimana pun, tidak serta-merta dapat terealisir dengan benar jika akad tidak ditopang oleh beberapa unsur pokok.

Ada empat unsur pokok yang harus melekat dalam akad, dan masing-masing unsur pun memiliki persyaratan tertentu, pertama, subjek akad. Subjek akad harus memiliki dua syarat yang mencakup syarat subjek yang terdiri dari beberapa pihak, dan subjek memiliki tingkat kecakapan hukum, yaitu cakap untuk menerima dan bertindak hukum, atau cakap untuk menerima hak dan kewajiban maupun cakap untuk mendapat pengakuan secara hukum (Islam) atas segala

9 Muḥammad Qadrī Bāshā, Murshid al-Hayrān ilā Márifat Aḅwāl al-Insān, Vol. 2 (Kairo: Dār al-Furjānī, 1983), 49.

${ }^{10}$ Syamsul Anwar, Hukum Perjanjian Syariah (Jakarta: Rajawali Press, 2007), 68. 
tindakannya, ${ }^{11}$ kedua, pernyataan kehendak para pihak. Pernyataan kehendak mereka sering disebut dengan sighat al-'aqd yang terdiri dari ijab dan kabul. Ijab dan kabul adalah suatu sighat yang menunjukkan kerelaan.

Kerelaan dapat terkonstruk jika ada persesuaian ijab dan kabul yang menandai persesuaian kehendak sehingga terwujud kata sepakat, dan persesuaian kehendak (kata sepakat) itu dicapai dalam satu majelis, ketiga, objek akad (mahal al-'aqd). Objek akad adalah suatu hal yang karenanya akad dibuat dan berlaku akibat-akibat hukum akad. Objek akad dapat berupa benda, manfaat benda, jasa atau pekerjaan, atau sesuatu yang tidak bertentangan dengan syariah dengan syarat; objek akad dapat diserahkan atau dapat dilaksanakan, objek akad harus tertentu atau dapat ditentukan, dan objek akad dapat ditransaksikan menurut shara',12 dan keempat, tujuan akad (mawdu' al'aqd), yaitu tujuan untuk mewujudkan akibat hukum dasar dari akad. Tujuan ini merupakan akibat hukum yang timbul dari sebuah perjanjian. Ia merupakan akibat hukum dasar dari maksud dan tujuan yang hendak direalisasikan oleh para pihak melalui akad.

Komponen akad di atas tentu tidak hanya berlaku dalam muamalah personal-individual sehari-hari tetapi juga berlaku dan telah diimplementasikan secara kelembagaan dalam bank syariah. Implementasinya di bank syariah lebih sederhana dan sebagian teradaptasi dari karakteristik yang dibangun melalui peta distribusi transaksi dalam produk-produk yang sudah berlaku pada lembaga keuangan konvensional. Adaptasi produk yang demikian bukan berarti adaptasi produk yang kontra dengan prinsip haläl tayyib dan shari tetapi harus tetap patuh dan tunduk pada ketentuan syariah (sharia compliance). Adaptasi beberapa produk yang demikian merupakan bentuk adopsi sistemik yang dibenarkan selama inline dengan prinsip dan nilai syariah. Akad muamalah adalah suatu akad yang mengatur dan mengikat berbagai pihak dalam transaksi produk bank syariah, sekalipun di antaranya, teradaptasi secara evolutif dari produk bank konvensional.

\footnotetext{
11 Wahbah al-Zuhaylī, al-Fiqh al-Islāmi wa Adillatuh, Vol. 4 (Damaskus: Dār al-Fikr, 1989), 116.

12 'Abd al-Razzāq al-Sanhūrī, Mașādir al-Haqq fì al-Fiqh al-Islāmì, Vol. 3 (Beirut: alMajma' al-'Ilm al-'Arabī al-Islāmī, t.th.), 36.
} 


\section{Hybrid Contract}

Kata bybrid (Inggris) kerap disebut dengan kata "hibrida" (Indonesia). ${ }^{13}$ Kata "hibrida" yang kali pertama digunakan untuk istilah bagi hasil persilangan antara dua individu dengan geneotype yang berbeda memiliki makna yang tumpang tindih dengan kata "bastar" atau "blaster". ${ }^{14}$ Kata "hibrida"- - terlepas dari soal overlap maknanya dengan "blaster"-dalam perkembangannya memang digunakan untuk beberapa istilah teknis dari disiplin ilmu yang berbeda, yaitu; a) hibrida yang merujuk pada jenis kultivar tanaman atau strain ternak, b) hibrida yang digunakan dalam bidang automotif, c) hibrida yang dipakai dalam bidang informatika, dan d) hibrida yang digunakan untuk merefleksikan aneka kesenian sebagai bentuk hibridasi dari dua atau lebih ragam kesenian standar.

Varian penggunaan kata "hibrida" secara harfiah memberikan fleksibilitas kontrak bybrid terhadap kontrak beragam yang dalam bahasa Indonesia dikenal dengan istilah "multiakad". Kata "multi" bermakna banyak; lebih dari satu, lebih dari dua; dan berlipat ganda. ${ }^{15}$ Jadi, multiakad adalah "akad ganda atau akad yang banyak, lebih dari satu". ${ }^{16}$ Sedangkan multiakad dalam istilah fikih adalah tarjamah dari istilah Arab al-"uqüd al-murakkabah yang bermakna "akad ganda" dan memuat dua unsur kata, al-uqüd (jamak dari mufrad al-'aqd) dan almurakkabah. Kata al'aqd, secara detail, telah dikaji di bagian awal, sehingga tidak perlu dibahas kembali makna harfiahnya, sementara kata al-murakkabah atau kata al-murakkab secara etimologis bermakna al-jam; yakni menggabungkan. Kata murakkab berasal dari akar kata rakkaba-yurakkibu-tarkib yang mengandung arti meletakkan sesuatu pada sesuatu yang lain sehingga menumpuk, ada yang di atas dan ada yang di bawah.

Hammād mendefinisikan al-'aqd al-murakkab sebagai "kesepakatan dua pihak untuk melakukan transaksi yang mengandung dua atau lebih akad". ${ }^{17}$ Kesepakatan yang dibangun atas akad ganda tentu memiliki dampak hukum yang sama dengan akibat hukum dari satu akad. ${ }^{18}$ Pandangan Hammād tidak berbeda dengan pandangan al-

\footnotetext{
13 Tim Penyusun, Kamus Besar Bahasa Indonesia, 398.

14 http://id.wikipedia.org/wiki/hibrida; http://dictionary.reference.com /browse/ hybrid

15 Tim Penyusun, Kamus Besar Bahasa Indonesia, 761.

16 Ibid.

${ }^{17}$ Hammād, al-Uqūd al-Murakkabah, 7.

18 Ibid.
} 
'Imrānī. Ia mengatakan bahwa al-'aqd al-murakkab adalah himpunan beberapa akad kebendaan yang dikandung oleh sebuah akad, sehingga semua hak dan kewajiban yang ditimbulkan pun dikatakan sama dengan akibat hukum dari satu akad. ${ }^{19}$

Kedua padangan tentang konsep akad di atas tidak menafikan munculnya pandangan ahli fikih yang lain untuk mengungkap ragam jenis atau istilah akad yang memiliki hubungan, kemiripan, dan bahkan kesamaan dengan makna al-'aqd al-murakekab, di antaranya adalah al-'uquid al-muta'addidah, al-'uqüd al-mujtami'ah, al- al-uquid almutadäkbilah, 'uqüd al-mutakarrirah, dan al-uqūd al-mukbtalitah. Al'Imrānī, dalam konteks ini, membagi al-'aqd al-murakekab, yang menjadi embrio bybrid contracts, ke dalam lima macam jenis akad. Kelima jenis akad ini mencakup al-'uqüd al-mutaqäbilah, al-'uqüd al-mujtami'ah, al-'uqüd al-mutanäqidah wa al-mutad̄àdah wa al-mutanäfìyah, al-'uqüd al-mukbtalifah, dan al-'uqüd al-mutajānisah. Dalam konteks ini, menurut 'Imrān, dua jenis akad yang pertama, al-uqüd al-mutaqäbilah, dan al-uqüd almujtami'ah, merupakan multiakad yang umum dipakai dibanding tiga jenis akad yang lain.

Akad jenis pertama, al-uqūd al-mutaqäbilah (akad bergantung/ bersyarat) adalah multiakad dalam bentuk bahwa akad kedua hadir untuk merespons akad pertama. Kehadiran akad kedua dapat mengkonstruk kesempurnaan akad pertama, dan karenanya, akad pertama bisa sempurna tergantung pada kesempurnaan akad kedua melalui proses interdependesi. ${ }^{20}$ Dalam kajian fikih, jenis akad yang demikian telah lama dikenal, dan bahkan praktiknya pun cukup menghiasi realitas banyak transaksi. Tidak sedikit ulama yang mengkaji tema ini baik tentang hukum atau tentang model pertukarannya, misalnya, antara akad tabarru' dengan akad tabarru', antara akad mu'awadah (pertukaran) dengan akad tabarru', atau antara akad pertukaran dengan akad pertukaran. Model akad yang demikian biasa dikonsepsikan ulama dengan model akad bersyarat. ${ }^{21}$ Sedangkan akad jenis kedua, al-uquid al-mujtami'ah (akad terkumpul), adalah akad ganda (dua atau lebih) yang terhimpun menjadi satu akad. Multiakad

19 'Abd Allāh b. Muhammad b. 'Abd Allāh al-'Imrānī, al-'Uqūd al-Mãliyah alMurakkabah: Dirāsah Fiqhìah Ta'silìyah wa Tatbiquiyah (Riyad: Dār Kunūz Eshbelia li al-Nashr wa al-Tawzī', 2006), 46.

${ }^{20}$ Imām Mālik b. Anas, al-Mudawwanah al-Kubrā, Vol. 4 (Beirut: Dār al-Ṣādir, 1323), 126.

21 al-'Imrānī, al-'Uqūd al-Māliyah, 57. 
mujtami 'ah ini bisa terjadi karena dua akad yang memiliki akibat hukum berbeda terkumpul dalam satu akad atas dua objek dengan satu harga, dua akad dalam satu akad yang berbeda hukumnya atas satu objek dengan satu imbalan atau dua akad yang akibat hukumnya berbeda dalam satu akad atas dua objek dengan dua harga, baik dalam waktu yang sama atau waktu yang berbeda.

Terlepas dari soal keumuman dua akad di atas, tiga jenis akad lainnya pun tetap urgen untuk dibahas. Jenis akad yang ketiga dan memuat tiga istilah yang berbeda, al-uqüd al-mutanäqidah wa almutadädah wa al-mutanäfiyah adalah akad yang bermakna berlawanan. Ketiga istilah dalam akad ini memiliki kesamaan bahwa ketiganya mengandung maksud dan implikasi yang berbeda. Mutanäqidah mengandung arti berlawanan, misalnya seseorang mengatakan "sesuatu" kemudian mengatakan lagi "sesuatu" yang berlawanan. Adapun makna etimologis dari mutadädah adalah dua keadaan yang mustahil bisa terkumpul dalam waktu yang sama, seperti antara siang dan malam. Sedangkan kata mutanäfiyah bermakna "menafikan", lawan dari "menetapkan". 22

Jenis akad yang lain, al-uqüd al-mukhtalifah, adalah jenis akad yang keempat yang menggabungkan dua akad atau lebih yang semua atau sebagian akibat hukumnya berbeda di antara kedua akad itu, seperti perbedaan akibat hukum dalam akad jual beli dan akad sewa. Dalam

22 Makna yang berbeda dari ketiga istilah mutanāqịah, mutadādah, dan mutanäfiyah ini telah dirumuskan oleh para ahli fikih dengan formula berikut, yaitu: a) dua akad yang kontradiktif sangat absurd untuk disatukan, b) dua sebab yang internegasional akan merefleksikan akibat yang juga saling meniadakan, sehingga akadnya pun tidak dapat digabung, c) dua akad yang praktiknya bertentangan dan akibat hukumnya yang berlawanan tidak dibenarkan untuk digabung, d) akad jual beli dan akad sharf tidak boeh bahkan haram digabung dalam satu akad, e) ada dua pendapat yang berbeda ketika menanggapi soal terkumpulnya akad ijarah dan akad jual beli, akad sharf dan akad jual beli dengan satu imbalan. Pendapat yang pertama menyebutkan bahwa kedua akad menjadi batal karena ada hukum dua akad yang bersebrangan dan tidak ada prioritas terhadap salah satu akadnya". Sedangkan menurut pendapat yang kedua, penggabungan dua akad dan imbalan yang dibagi untuk dua akad atas dasar harga setiap objek akad adalah sah dan tidak membatalkan akad, dan f) dua akad yang terhimpun atas objek yang memiliki harga berbeda dengan satu imbalan hukumnya sah, karena keduanya dapat dimintakan imbalan sesuai harganya masingmasing. Namun pendapat lain memandangnya tidak sah karena memiliki diktum hukum yang berbeda. Perbedaan pandangan tersebut jelas menunjukkan bahwa multiakad yang mutanāqidah, mutadādah, dan mutanäfiyah adalah akad-akad yang tidak boleh digabung menjadi satu akad, walaupun pandangan ulama terhadap tiga bentuk multiakad itu beragam. Lihat Ibid. 
akad jual beli tidak harus ada ketentuan waktu, sedangkan dalam akad sewa justru sebaliknya. Contoh lain adalah akad ijärah dan akad saläm. Dalam akad ijärah, harga sewa tidak harus diserahkan pada saat akad, sementara dalam saläm, harga saläm harus diserahkan pada saat akad $(f i$ al-majlis).

Adapun akad yang kelima adalah akad sejenis (al-uqūd almutajānisah), yaitu akad-akad yang mungkin dihimpun dalam satu akad, namun tidak mempengaruhi hukum dan akibat hukumnya. Multiakad jenis ini dapat terdiri dari satu jenis akad seperti akad jual beli dan akad jual beli, atau dari beberapa jenis seperti akad jual beli dan sewa menyewa. Multiakad jenis ini dapat pula terbentuk dari dua akad yang memiliki hukum yang sama atau berbeda.

\section{Sistem Gadai dalam Normativitas DSN-MUI}

Sistem gadai yang dimaksud dalam tema ini adalah suatu sistem yang dikonstruk berdasarkan regulasi DSN-MUI. Regulasi tentang gadai merupakan aturan regulatif DSN-MUI No. 26/DSNMUI/III/2002 dan No. 92/DSN-MUI/IV/2014 yang mengatur soal gadai karena peran sentral DSN-MUI dalam mengawal dan menjamin kemurnian keuangan syariah. DSN yang dibentuk oleh MUI pada tahun 1998 memiliki peran sentral dan strategis yang keberadaannya dikukuhkan berdasarkan Surat Keputusan MUI No. Kep754/MUI/II/1999 tanggal 10 Februari 1999. Surat keputusan MUI memiliki kekuatan untuk membangun dan mendayagunakan fungsi utama DSN-MUI dalam mengawasi produk-produk lembaga keuangan syariah agar sesuai dengan syariah Islam.

Pengawasan DSN-MUI terhadap lembaga keuangan syariah dilakukan dengan format panduan produk syariah yang jelas dan bersumber dari sumber-sumber hukum Islam. DSN-MUI selain memiliki fungsi pengawasan juga memiliki fungsi meneliti dan memberi fatwa bagi produk-produk yang dikembangkan oleh lembaga keuangan syariah. Selain itu, DSN-MUI juga memberikan rekomendasi para ulama yang akan ditugaskan oleh DSN-MUI pada suatu lembaga keuangan syariah, bahkan DSN-MUI dapat memberikan teguran kepada lembaga keungan syariah jika lembaga yang bersangkutan menyimpang dari garis panduan yang telah ditetapkan. Hal ini dilakukan jika DSN-MUI menerima laporan dari dewan pengawas syariah pada lembaga yang bersangkutan mengenai hal tersebut. 
Jika lembaga keuangan syariah tersebut tidak mengindahkan teguran yang diberikan, DSN-MUI dapat mengusulkan kepada lembaga yang memiliki otoritas untuk memberikan sanksi agar tidak mengembangkan tindakan lebih jauh yang tidak sesuai dengan syariah. ${ }^{23}$ Namun sebaliknya lembaga keuangan syariah dapat mengajukan produk-produk baru jika lembaga tersebut dinilai memiliki kinerja yang baik dan menunjukkan sharia compliance-nya. Sharia compliance yang ditampilkan oleh lembaga keuangan syariah dapat mendorong dewan pengawas syariah untuk ikut merekomendasikan kehadiran produk baru sesuai tata aturan yang berlaku. Aturan rahn adalah aturan yang berlaku yang dikeluarkan oleh DSN-MUI No. 92/DSN-MUI/IV/2014 sebagai pengganti dari keputusan DSN-MUI No. 26/DSN-MUI/III/2002. Aturan ini memuat diktum bahwa semua bentuk pembiayaan dan/atau penyaluran dana lembaga keuangan syariah boleh dijamin dengan agunan $(r a h n)$ sesuai fatwa DSN-MUI di atas yang memuat beberapa ketentuan berikut.

Pertama, ketentuan terkait barang jaminan (marbūn). Ketentuan ini mencakup; a) barang jaminan (marbinn) harus berupa harta (māl) berharga baik harta bergerak maupun tidak bergerak yang boleh dan dapat diperjualbelikan, termasuk aset keuangan berupa sukuk, efek syariah atau surat berharga syariah lainnya, b) dalam hal barang jaminan (marbün) merupakan musha' (bagian dari kepemilikan bersama, maka musha' yang digadaikan harus sesuai dengan porsi kepemilikannya, c) barang jaminan (marbün) boleh diasuransikan sesuai peraturan perundang-undangan yang berlaku dan/atau kesepakatan.

Kedua, ketentuan terkait utang (marhün bih/'ayn). Ketentuan tentang utang meliputi; a) utang boleh dalam bentuk uang dan/atau barang, b) utang harus bersifat mengikat (lä̌rim) yang tidak mungkin dihapus kecuali setelah dibayar atau dibebaskan (fatwa DSN-MUI Nomor: 11/DSN-MUI/IV/2000 tentang kafälah (Ketentuan Kedua, 4.c), c) utang harus jelas jumlah (kuantitas) dan/atau kualitasnya serta jangka waktunya, d) utang tidak boleh bertambah karena perpanjangan jangka waktu pembayaran. Jika jangka waktu pembayaran utang/pengembalian modal diperpanjang, maka lembaga keuangan syariah dapat mengenakan ta'wì dan ta'zị dalam hal räbin melanggar perjanjian atau terlambat menunaikan kewajibannya, dan 2)

23 Bank Indonesia, Petunjuk Pelaksanaan Pembukaan Kantor Bank Syari'ab (Jakarta: Bank Indonesia, 1999). 
mengenakan pembebanan biaya riildalam hal jangka waktu pembayaran utang diperpanjang.

Ketiga, ketentuan terkait akad, meliputi; a) pada prinsipnya, akad rahn dibolehkan hanya atas utang-piutang (al-dayn) yang antara lain timbul karena akad qard, jual beli (al-bay) yang tidak tunai, atau akad sewa-menyewa (jjärab) yang pembayaran ujrabnya tidak tunai, b) pada prinsipnya dalam akad amanah tidak dibolehkan adanya barang jaminan (marbün), namun agar pemegang amanah tidak melakukan penyimpangan perilaku (moral bazard), lembaga keuangan syariah boleh meminta barang jaminan (marbinn) dari pemegang amanah (alamin, antara lain shärik, mudärib, dan mustajir) atau pihak ketiga, c) barang jaminan (marbün) dalam akad amanah hanya dapat dieksekusi apabila pemegang amanah (al-amin, antara lain shärik, mudärib, dan mustajir) melakukan perbuatan moral hazard, yaitu: 1) ta'addi (ifrat), yaitu melakukan sesuatu yang tidak boleh/tidak semestinya dilakukan, 2) taqsìr (tafrìt), yaitu tidak melakukan sesuatu yang boleh/semestinya dilakukan, atau 3) mukhallafat al-shurüt, yaitu melanggar ketentuanketentuan (yang tidak bertentangan dengan syariah) yang disepakati pihak-pihak yang berakad.

Keempat, ketentuan terkait pendapatan murtabin. Ketentuan yang berkaitan dengan pendapatan murtabin mencakup; a) dalam hal rabn (dayn/marbün bih) terjadi karena akad jual-beli (al-bay) yang pembayarannya tidak tunai, maka pendapatan murtabin hanya berasal dari keuntungan (al-ribḥ) jual-beli, b) dalam hal rahn (dayn/marbün bib) terjadi karena akad sewa-menyewa (ijärah) yang pembayaran ujrah-nya tidak tunai, maka pendapatan murtahin hanya berasal dari ujrah, c) dalam hal rabn (dayn/marbün bib) terjadi karena peminjaman uang (akad qard), maka pendpatan murtabin hanya berasal dari mu'nab (jasa pemeliharaan/penjagaan) atas marbün yang besarnya harus ditetapkan pada saat akad sebagaimana ujrah dalam akad ijōrah, d) dalam hal rabn dilakukan pada akad amanah, maka pendapatan/penghasilan murtahin (shärik/șähib al-mā̄) hanya berasal dari bagi hasil atas usaha yang dilakukan oleh pemegang amanah (shärik-pengelola/mudärib).

Kelima, ketentuan terkait penyelesaian akad rahn. Penyelesaian akad rahn harus memenuhi ketentuan yang meliputi; a) akad rahn berakhir apabila räbin melunasi utangnya atau menyelesaikan kewajibannya dan murtahin mengembalikan marbün kepada rähin, b) dalam hal rähin tidak melunasi utang nya atau tidak menyelesaikan kewajibannya pada waktu yang telah disepakati, maka murtahin wajib mengingatkan/ 
memberitahukan tentang kewajibannya, c) setelah dilakukan pemberitahuan/peringatan, dengan memperhatikan asas keadilan dan kemanfaatan pihak-pihak, murtabin boleh melakukan hal-hal; 1) menjual paksa barang jaminan (marbün) sebagaimana diatur dalam substansi fatwa DSN-MUI Nomor: 25/DSN-MUI/III/2002 tentang rahn (ketentuan ketiga angka 5); atau 2) meminta rähin agar menyerahkan marbün untuk melunasi utangnya sesuai kesepakatan dalam akad, di mana penentuan harganya mengacu/berpatokan pada harga pasar yang berlaku pada saat itu. Dalam hal terdapat selisih antara harga (thaman) jual marbinn dengan utang (dayn) atau modal ( $\mathrm{ra}$ 's al-mā), berlaku substansi fatwa DSN-MUI Nomor: 25/DSNMUI/III/2002 tentang rabn.

Jika keputusan tersebut muncul atas pertimbangan fatwa-fatwa DSN-MUI terkait rahn dan dipandang belum mengakomodasi pengembangan usaha berbasis rahn, maka lembaga keuangan syariah memerlukan fatwa terkait pengembangan usaha berbasis rabn. Fatwafatwa yang dikeluarkan oleh DSN-MUI tentu tetap didasarkan pada sumber-sumber hukum Islam, baik al-Qur'ān, Hadīth, maupun ijmā' ulama sebagai berikut.

1. Firman Allah dalam surah al-Baqarah ayat 283.

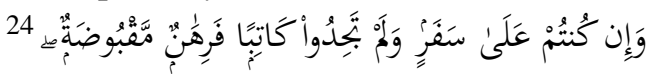

"Dan apabila kalian dalam perjalanan sedang kalian tidak memperoleh seorang juru tulis maka hendaklah ada barang tanggungan yang dipegang".

2. Firman Allah dalam surah al-Mā’idah ayat 1.

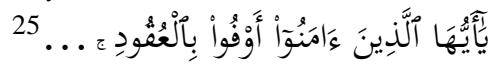

"Hai orang yang beriman! Tunaikanlah akad-akad itu ...".

3. Firman Allah dalam surah al-Isrä' ayat 34

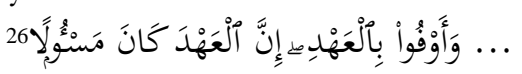

“... Dan tunaikanlah janji-janji itu, sesungguhnya janji itu akan dimintai pertanggungjawaban”.

${ }^{24}$ Al-Qur'an, 2: 283.

25 Al-Qur'an, 5: 1.

26 Al-Qur'an, 17: 34. 
4. Hadīth Nabi riwayat al-Bukhārī dan Muslim dari 'Āishah.

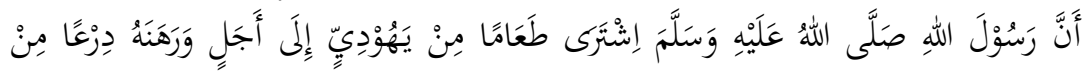

"Sesungguhnya Rasulullah pernah membeli makanan dengan berutang dari seorang Yahudi, dan Nabi menggadaikan sebuah baju besi kepadanya".

5. Hạadīth Nabi riwayat al-Shāfí̄í, al-Dāraquṭn̄̄ dan Ibn Mājah dari Abū Hurayrah.

$$
\text { لاَ يَغْلَقُ الرَّهْنُ مِنْ صَاحِبِهِ اللَّذِيْ رَهَنَهُ، لَهُ غُنْنُهُ وَعَلَيْهِ غُرْمُهُ }
$$

“Tidak terlepas kepemilikan barang gadai dari pemilik yang menggadaikannya. Ia memperoleh manfaat dan menanggung risikonya".

6. Hadīth Nabi riwayat Jamā'ah, kecuali Muslim dan al-Nasā'̄ .

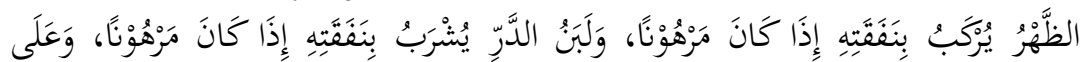

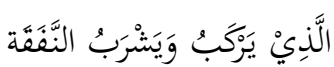

"Tunggangan (kendaraan) yang digadaikan boleh dinaiki dengan menanggung biayanya dan binatang ternak yang digadaikan dapat diperah susunya dengan menanggung biayanya. Orang yang menggunakan kendaraan dan memerah susu tersebut wajib menanggung biaya perawatan dan pemeliharaan".

7. Ijmă ulama. Para ulama sepakat membolehkan akad rahn.27

8. Kaidah fikih.

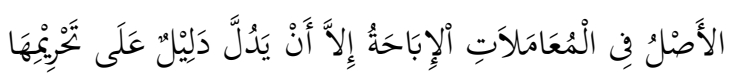

"Pada dasarnya, semua bentuk muamalah boleh dilakukan kecuali ada dalil yang mengharamkannya". ${ }^{28}$

Sistem gadai yang dikonstruk berdasarkan aturan normatif DSNMUI di atas, bagaimanapun, merupakan sistem akad gadai (rabn) yang

${ }^{27}$ al-Zuhaylī, al-Figh al-Islàmì wa Adillatuh, Vol. 5, 181.

${ }^{28}$ Kaidah fikih yang dijadikan dasar oleh DSN-MUI ini juga dapat dilihat dalam kaidah fikih lainnya, yaitu a) al-Aș fì al-'uqüd wa al-mu'ämalät al-șị̣hah ḥattà yaqüma dalīl 'alà al-butlān wa al-taḥim, lihat Muḥammad b. Abī Bakr Ayyūb al-Zar'ī Abū 'Abd Allāh b. Qayyim al-Jawzī, I'lām al-Muwaqqì̛n (Riyāḍ: Dār Ibn al-Jawzī, 1423); b) Anna al-asl fì al-ashyā' al-makblūqah al-ibāḥah hattā yaqüma dalīl yadullu 'alā al-naql 'alā hādhā al-așl, lihat Muḥammad b. 'Alī b. Muḥammad al-Shawkānī, Fatḥ al-Qadìr, Vol. 1 (Beirut: Dār al-Ma'rifah, 2013), 64; dan c) al-Așl fì al-ashyà' al-ibāḥah ḥattā yadulla aldalīl 'alā al-tahrìm, lihat Jalāl al-Dīn 'Abd al-Raḥmān al-Suyūṭi, al-Ashbāh wa al-Nažāìr fì Qawāid wa Furū' Fiqh al-Shäfícyah (Beirut: Dār al-Kutub al-'Ilmìyah, 1983), 82. 
memungkinkan bahkan mengharuskan adanya jaminan aset. Rahn atau yang lebih sering digunakan untuk istilah marbün, dalam konsep syariah, adalah harta yang dijadikan jaminan kepercayaan dalam hutang yang nilainya dapat digunakan untuk melunasi tanggungan (hutang) jika beban utangnya tidak dapat dibayar oleh orang yang berhutang. ${ }^{29}$ Dalam realitas masyarakat, praktik gadai yang menjadikan aset sebagai jaminan kepercayaan banyak dijumpai dalam contoh sederhana, misalnya, A memiliki kendaraan sepeda motor. A tidak memiliki uang, dan A berkeinginan untuk berhutang kepada B sebesar Rp. 15 juta. Sepeda motor A kemudian dijadikan jaminan kepercayaan untuk hutang tersebut. Jika suatu saat A tidak mampu membayar dan melunasinya, maka B diperbolehkan untuk menjual aset sepeda motor itu dengan izin $\mathrm{A}$.

Realitas hutang-piutang dengan jaminan aset di atas tidak hanya terjadi antara orang dengan orang tetapi juga terjadi antara lembaga keuangan syariah dengan nasabahnya seperti yang digambarkan dalam realitas gadai di Bank Mega Syariah (selanjtunya disebut BMS). ${ }^{30}$ Praktik gadai emas di BMS berlangsung melalui sistem akad gadai yang mencakup komponen utama, yaitu rukun dan syarat sah gadai, biaya-biaya, dan prosedur penyelesaian barang jaminan. Sistem yang demikian adalah suatu sistem standar yang keberadaannya diakui bahkan menjadi standar baku di BMS.

Standar baku yang memuat rukun dan syarat sah gadai emas pada BMS adalah jjāb dan qabül, murtabin (BMS), rähin (nasabah), dan marbün (emas). BMS menerapkan beberapa syarat untuk rähin dan marbün. Terhadap marbūn tersebut, BMS tidak berhak memanfaatkan barang tersebut. BMS hanya menyimpannya sebagai salah satu bentuk jaminan kepercayaan bahwa nasabah akan mengembalikan pinjamannya tepat waktu. İjäb dan qabül yang terdapat dalam Surat Bukti Gadai di BMS menjadi unsur penting yang keberadaannya tidak dapat dipisahkan dengan unsur lainnya. Berbagai persyaratan dan biaya-biaya yang melekat harus diketahui oleh para pihak saat ijäb dan qabül berlangsung.

Berbagai biaya di BMS baik biaya administrasi maupun biaya sewa tempat memang tertuang dalam kontrak gadai atau dalam konteks

${ }^{29}$ Ibn Qudāmah, al-Mughnì, Vol. 4. Kairo: Dār 'Ālam al-Kutub, 1997), 326.

${ }^{30}$ Nadhifatul Kholifah, Topowijono, dan Devi Farah Azizah, "Analisis System dan Prosedur Gadai Emas Syariah: Studi pada PT. Bank Mega Syariah dan PT. Bank BNI Syariah Kantor Cabang Malang", Jurnal Administrasi Bisnis, Vol. 5, No. 1 (2013). 
BMS, kontrak adalah Surat Bukti Gadai. Biaya sewa tempat yang ditetapkan dalam kontrak tidak didasarkan pada jumlah pinjamannya tetapi didasarkan pada kadar karat dalam emas tersebut, misalnya, berat emas dan jangka waktu gadai. Biaya sewa dikeluarkan dengan memperhitungkan seluruh pembiayaan yang meliputi; biaya pemeliharaan, biaya keamanan, dan biaya asuransi.

Beban pembiayaan yang demikian, oleh BMS, mengacu pada aturan DSN-MUI No. 26/DSN-MUI/III/2002 yang menyatakan bahwa 1) gadai emas dibolehkan berdasarkan prinsip rahn (lihat Fatwa DSN-MUI No. 25/DSN-MUI/III/2002 tentang rahn), 2) ongkos/ biaya penyimpanan barang ditanggung oleh penggadai (rähin), 3) ongkos sebagaimana dimaksud pada ayat 2 besarannya didasarkan pada pengeluaran yang nyata-nyata diperlukan, dan 4) biaya penyimpanan barang dilakukan berdasarkan akad ijärah.

Barang jaminan (marbün) sebagai garansi pembiayaan gadai tidak sekadar suatu barang tetapi juga barang yang dibenarkan sesuai aturan DSN-MUI. DSN-MUI No. 92/DSN-MUI/IV/2014 mengatur jaminan gadai dengan batasan bahwa "barang jaminan harus berbentuk harta benda berharga baik benda bergerak maupun benda tidak bergerak yang boleh dan dapat diperjualbelikan, termasuk aset keuangan berupa sukuk, efek syariah, dan surat berharga syariah lainnya". ${ }^{31}$ Dalam hal barang jaminan merupakan musha' (bagian dari kepemilikan bersama), maka "musha' yang digadaikan harus sesuai dengan porsi kepemilikannya". 32 Barang jaminan boleh diasuransikan sesuai peraturan perundang-undangan yang berlaku dan/atau kesepakatan.

Ketika barang dipersyaratkan secara ketat karena menjadi jaminan terhadap hutang dalam sistem gadai, maka ketentuan tentang hutang pun diatur sedemikian rupa dalam aturan DSN-MUI bahwa "utang boleh dalam bentuk uang dan/atau barang, utang bersifat mengikat (lärim) yang tidak dapat dihapus kecuali telah dibayar atau dibebaskan (fatwa DSN-MUI Nomor: 11/DSN-MUI/IV/2000 tentang kafälah), utang harus jelas kuantitas dan/atau kualitasnya serta jangka waktunya, dan utang tidak boleh bertambah karena perpanjangan

31 Habib Wakidatul Ihtiar, "Analisis Fatwa Dewan Syariah Nasional Nomor: 92/DSN-MUI/IV/2014 tentang Pembiayaan yang Disertai Rahn”, An-Nisbab: Jurnal Ekonomi Syariah, Vol. 3, No. 1 (Oktober, 2016).

${ }^{32}$ Ibid. 
jangka waktu pembayaran". ${ }^{33}$ Jika jangka waktu pembayaran utang/pengembalian modal diperpanjang, maka lembaga keuangan syariah dapat mengenakan; a) ta'widh dan ta'zir dalam hal rähin melanggar perjanjian atau terlambat menunaikan kewajibannya, dan b) pembebanan biaya riil dalam hal jangka waktu pembayaran utang diperpanjang. ${ }^{34}$

\section{Sistem Gadai dalam Konteks Litigasi Fikih}

Kebutuhan masyarakat saat ini sangat kompleks, bahkan karena kompleksitasnya, lembaga keuangan syariah dituntut untuk memenuhi kebutuhan tersebut. Kebutuhan masyarakat yang variatif tidak mungkin dapat direspons dan dipenuhi bila lembaga keuangan syariah tidak melakukan inovasi produk-produknya. Inovasi berbagai produk pun tidak dapat dilakukan jika tidak didukung oleh inovasi akad karena akad-akad yang standar dan dibiarkan dalam format asalnya tidak kuasa untuk menjangkau realitas transaksi keuangan modern. Kreativitas dan inovasi akad dalam bentuk penggabungan beberapa akad (bybrid contract) adalah suatu keharusan.

Kaharusan untuk mengombinasikan akad dengan tetap tidak melanggar substansi akad umumnya didasarkan pada suatu kaidah fikih yang telah ditetapkan ulama salaf yang berbunyi al-mubăfazah 'alā al-qadim al-sälih wa al-akbdh bi al-jadì al-aslah. Kaidah ini dijadikan sebagai salah satu instrumen ketika MUI mengkaji dan menetapkan produk-produk, termasuk produk gadai syariah, yang diimplementasikan dalam lembaga keuangan syariah.

Produk gadai dipandang sebagai salah satu produk yang kelahirannya dipersiapkan untuk merespons kebutuhan masyarakat. Produk gadai menurut definisi DSN-MUI No. 26/DSNMUI/III/2002 adalah bentuk jasa pelayanan yang menahan barang sebagai jaminan atas utang. Jaminan kepercayaan dan ketentuan yang inheren di dalamnya kemudian DSN-MUI jelaskan karena berkaitan dengan keputusan DSN-MUI yang membolehkan rahn dalam lembaga keuangan syariah. Ada empat diktum yang dijelaskan DSN-MUI, yaitu: 1) jaminan emas dibolehkan berdasarkan prinsip rabn, 2) ongkos dan biaya penyimpanan barang (marbün) ditanggung oleh penggadai (rähin), 3) ongkos sebagaimana dimaksud pada ayat 2 besarnya

33 Dewan Syariah Nasional Majelis Ulama Indonesia, "Fatwa", dalam https://dsnmui.or.id/produk/fatwa/1, diakses pada 19 September 2017.

${ }^{34}$ Ibid. 
didasarkan pada pengeluaran riil, dan 4) biaya penyimpanan barang (marbün) berbasis akad ijārah.

Aturan gadai poin 2, 3 dan 4 di atas menunjukkan bahwa nasabah dikenakan biaya penyimpanan atas barang jaminannya dengan penggunaan akad ijarah sebagai akad sewa tempat untuk barang jaminan. Beberapa diktum di atas pun, dalam pelaksanaannya, menuntut penerapan akad yang sesuai dan dapat mengakomodir beberapa persyaratan dan pembiayaannya. Karenanya, lembaga keuangan syariah menggunakan akad bybrid, yaitu menggabungkan akad gadai, hutang dan ijärah dalam satu transaksi gadai. Penggabungan akad yang demikian, sekalipun didasarkan pada aturan DSN-MUI, tetap menuai kontroversi. Al-'Imrānī, misalnya, mengatakan bahwa syariah tidak membolehkan dua akad dalam satu transaksi akad (two-in-one) ${ }^{35}$ sesuai dengan hadīth berikut.

1. Larangan bay'atān fi bay'ah (dua jual beli dalam satu jual beli) riwayat Muslim. ${ }^{36}$

$$
\begin{aligned}
& \text { حدثنا هناد حد ثنا عبدة بن سليمان عن محمد بن عمرو عن ابي سلمة عن ابي هريرة }
\end{aligned}
$$

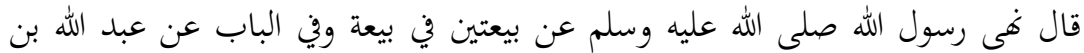

$$
\begin{aligned}
& \text { عمرو وابن عمر وابن مسعود قال ابو عيسى حديث ابي هريرة حديث حسن صحيح و } \\
& \text { العمل على هذا عند اهل العلم صحيح وقد فسر بعد اهل العلم قالوا بيعتين في بيعة ان } \\
& \text { يقول ابيعك هذا الثوب بنقد بعشرة وبنسيئة بعشرين ولايفارقه على احد البيعين فاءذا }
\end{aligned}
$$

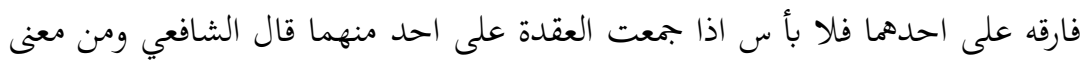

$$
\begin{aligned}
& \text { جملهى النبي صلى الله عليه وسلم عن بيعتين في بيعة ان يقول ابيعك داري هذه بكذا }
\end{aligned}
$$

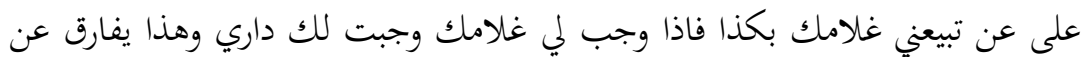

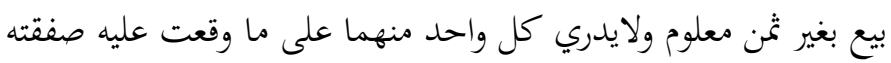

Beberapa riwayat tersebut menujukkan bahwa "Nabi telah melarang dua jual beli (pembelian) dalam satu jual beli (pembelian)".

2. Larangan safqatān fi safqah (dua kesepakatan dalam satu kesepakatan). ${ }^{37}$

\footnotetext{
35 al-'Imrānī, al- Uqūid al-Māliyah, 57.

36 Muslim b. al-Hajjầ, Șaḥ̣̄̄ Muslim, Vol. 5 (Beirut: Dār Ihyā̄' al-Turāth al-'Arabī, t.th.), 7 .
} 


$$
\begin{aligned}
& \text { حدثنا حسن وابو النضر وأسود بن عامر قالوا حدثنا شريك عن سماك عن عبد الرحمن } \\
& \text { بن عبد الله بن مسعود رضي الله عنهما عن أبيه قال غهى رسول الله صلى الله عليه وسلم }
\end{aligned}
$$

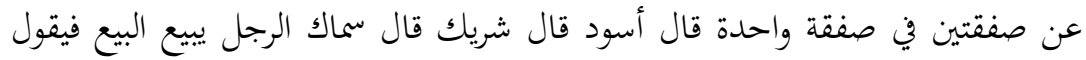

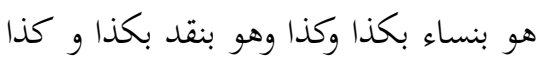

Riwayat tersebut bermakna: "Rasululllah telah melarang dua kesepakatan (akad) dalam satu kesepakatan (akad)." Maksud hadīth tersebut adalah bahwa Rasulullah dengan tegas melarang praktik dua akad (kesepakatan) dalam satu akad (kesepakatan).

3. Larangan bay "dan salaf (jual beli dan akad pemesanan barang)..$^{38}$

$$
\begin{aligned}
& \text { حدثنا أبوبكر الحنفي حدثنا الضحاك بن عثمان عن عمرو بن شعيب عن أبيه عن جده }
\end{aligned}
$$

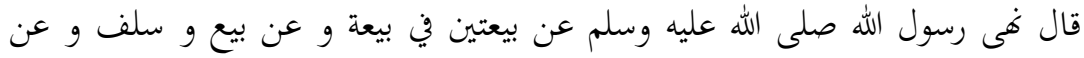

$$
\begin{aligned}
& \text { ربح مالم يضمن وعن بيع ماليس عندك رسول صله }
\end{aligned}
$$

Riwayat tersebut menunjukkan makna bahwa "Rasululllah telah melarang jual beli dan akad pemesanan barang (dalam satu transaksi)." Hadìth ini menegaskan larangan dalam dua konteks hadīth sebelumnya dengan disertai contoh kasus, yaitu akad salaf, atau akad pemesanan barang dengan pembayaran di depan, atau semacam inden barang, dengan akad jual-beli dalam satu transaksi atau akad.

Dalälah di atas baik yang menggunakan lafal nahā (melarang) maupun là tahiill atau là yahillu (tidak halal) menunjukkan bahwa hukum muamalah yang disebutkan dalam hadìth tersebut jelas haram karena ada lafal yang dengan jelas menunjukkan keharamannya. Meskipun ada pelarangan terhadap bybrid contract, namun kata al'Imrānī, larangan two-in-one terbatas pada tiga kasus yang dilarang dalam hadīth, yaitu larangan bay'atān $f i$ bay'ah, larangan safqatān $f i$ safqah, dan larangan bay' dan salaf.

Jika hadīth tersebut dikaitkan dengan aturan DSN-MUI tentang rahn dan di dalam akad rahn menyiratkan hutang, maka praktik rahn terkena pelarangan hadīth tentang larangan bay ' dan salaf. Dalam konteks ini, Ibn Qayyim berpendapat bahwa "Nabi melarang

${ }^{37}$ Aḥmad b. Hanbal, Musnad al-Imām Aḥmad b. Hanbal, Vol. 8 (Kairo: Mu'assasat alRisālah, 2009), 130.

${ }^{38}$ Ibid., Vol. 13, 377. 
multiakad antara akad salaf (memberi pinjaman [qard]) dan jual beli [bay.]". ${ }^{39}$ Bahkan menurutnya, semua akad yang mengandung unsur jual beli dilarang untuk digabung dengan qard dalam satu transaksi, seperti antara ijärb dan qard, salam dan qard, sarf dan qard, dan sebagainya. ${ }^{40}$

Meski penggabungan qard dan jual beli dilarang, namun menurut al-'Imrānī penggabungannya tidak selamanya dilarang. Penggabungan dua akad ini diperbolehkan apabila tidak ada syarat di dalamnya dan tidak ada tujuan untuk melipatgandakan harga melalui qard. Seperti seseorang yang memberikan pinjaman kepada orang lain, lalu beberapa waktu kemudian ia menjual sesuatu kepadanya padahal ia masih dalam rentang waktu qard tersebut. Model transaksi yang demikian hukumnya boleh. ${ }^{41}$

Setiap multiakad yang mengantarkan pada yang haram, seperti riba, hukumnya haram, meskipun akad-akad yang membangunnya adalah boleh. Penghimpunan beberapa akad yang hukum asalnya boleh namun berimplikasi kepada yang dilarang menyebabkan hukumnya menjadi dilarang. Hal ini terjadi pada multiakad antara akad salaf dan jual beli, seperi dijelaskan sebelumnya bahwa Nabi melarang multiakad antara akad jual beli dan salaf. Larangan ini disebabkan karena upaya mencegah jatuh kepada yang diharamkan berupa transaksi ribawi. Jumhur ulama melarang praktik multiakad ini, yakni terjadinya penghimpunan akad jual beli (mu'äwadab) dengan pinjaman (qard) apabila dipersyaratkan. Jika transaksi multiakad ini terjadi secara tidak disengaja diperbolehkan karena tidak adanya rencana untuk melakukan qard yang mengandung riba. ${ }^{42}$

Pada bagian lain, pandangan fikih kontemporer tentang status hukum multiakad belum tentu sama dengan status hukum dari akadakad yang membangunnya, seperti akad bay 'dan salaf yang secara jelas dinyatakan keharamannya oleh Nabi. Namun jika kedua akad itu berdiri sendiri-sendiri, maka baik akad bay' maupun akad salaf diperbolehkan. Begitu juga dengan menikahi dua wanita yang bersaudara sekaligus haram hukumnya, tetapi jika dinikahi satu-satu

\footnotetext{
39 Ibn Qayyim al-Jawzìyah, I'làm al-Muwaqqi'in 'an Rab al-'Álamin, Vol. 3 (Kairo: Maktabat Ibn Taymìyah, t.th.), 153.

40 Ibid.

${ }^{41}$ al-'Imrānī, al-'Uqüd al-Māliyah, 180.

42 Abū Zakariyā Yahyā b. Sharaf al-Nawāwī, Rawḍtat al-Tālibìn, Vol. 3 (Beirut: Dār alKutub, 1412), 398.
} 
(tidak dimadu) hukumnya boleh. Artinya, hukum multiakad tidak bisa serta merta dilihat dari hukum akad-akad yang membangunnya. Bisa jadi akad-akad yang membangunnya adalah boleh ketika berdiri sendiri, namun menjadi haram ketika akad-akad itu terhimpun dalam satu transaksi. Ketentuan seperti ini pernah disampaikan al-Shāṭibī. Ia mengatakan bahwa al-Istigrä' min al-shar' 'urf inna li al-ijtima' ta'thì fì aḅkàm là takünu hạlat al-infiräd (penelitian terhadap hukum Islam menunjukkan bahwa dampak hukum dari suatu kumpulan (akad) tidak sama seperti saat akad itu berdiri sendiri-sendiri).

Dari beberapa pandangan di atas, hukum dari multiakad belum tentu sama dengan hukum dari akad-akad yang membangunnya, artinya, hukum akad-akad yang membangun tidak secara otomatis menjadi hukum dari multiakad tersebut. Meski ada multiakad yang diharamkan, namun prinsip dari multiakad ini adalah boleh dan hukum dari multiakad diqiyaskan dengan hukum akad yang membangunnya. Jadi, setiap muamalah yang menghimpun beberapa akad, hukumnya halal selama akad-akad yang membangunnya adalah boleh. Ketentuan ini memberi peluang pada pembuatan model transaksi yang mengandung multiakad. Ketentuan ini berlaku umum, sedangkan beberapa hadīth Nabi dan nașs-naș̣ lain yang mengharamkan multiakad adalah ketentuan pengecualian. Hukum pengecualian ini tidak bisa diterapkan dalam segala praktik muamalah yang mengandung multiakad. ${ }^{43}$

Ulama berbeda pendapat tentang hukum asal dari multiakad. Perbedaan ini menyangkut apakah multiakad sah dan diperbolehkan atau batal dan dilarang untuk dipraktikkan. Mengenai hal ini ulama memang berada dalam dua pendapat yang berbeda; membolehkan dan melarang. Mayoritas ulama Hanafiyah, sebagian pendapat ulama Mālikīyah, ulama Shāfíīyah, dan Hanbalī berpendapat bahwa hukum multiakad sah dan diperbolehkan menurut syariat Islam. Pendapat yang pertama dan yang membolehkan multiakad beralasan bahwa hukum asal dari akad adalah boleh dan sah, tidak diharamkan dan dibatalkan selama tidak ada dalil hukum yang mengharamkan atau membatalkannya. ${ }^{44}$ Kalangan Mālikīyah dan Ibn Taymīyah pun berpendapat bahwa multiakad merupakan jalan keluar dan kemudahan yang diperbolehkan dan disyariatkan selama mengandung manfaat dan tidak dilarang agama, karena hukum asalnya adalah

${ }^{43}$ Hammād, al- Uqūd al-Murakkabah, 11-12.

${ }^{44}$ Ibid. 
sahnya syarat untuk semua akad selama tidak bertentangan dengan agama dan bermanfaat bagi manusia.

Kebolehan multiakad yang didasarkan atas prinsip hukum asal dari akad adalah boleh dan hukum multiakad diqiyaskan dengan hukum akad-akad yang membangunnya tetap harus memperhatikan ketentuan-ketentuan agama yang membatasinya. Artinya, meskipun multiakad diperbolehkan, namun tetap ada batasan-batasan yang tidak boleh dilanggar, karena batasan itu menjadi rambu bagi multiakad agar tidak terjerumus kepada praktik muamalah yang diharamkan. Sebaliknya, pendapat yang kedua justeru tidak setuju dengan kehadiran multiakad. Multiakad yang diatur dalam DSN-MUI tersebut tergolong dan terkena larangan bybrid contract bahwa dalam gadai emas, misalnya, terjadi pengambilan manfaat dan pemberian utang. Walaupun pengambilan manfaat tersebut disebut $u j r a h$ atas jasa penitipan, namun hakikatnya hanya rekayasa hukum (bilah) untuk menutupi riba di dalamnya dengan cara pengambilan manfaat dari pemberian utang baik berupa tambahan hadiah atau manfaat lainnya. Padahal manfaatmanfaat ini jelas merupakan riba yang haram seperti hadìth Nabi, kull qard jarra manfa' ah fabuwa riban.

Hạīith di atas diperkuat dengan hadīth lain yang berbunyi "Jika seseorang memberi pinjaman (qard), janganlah dia mengambil hadiah". Ibn Mundhir juga mendukung larangan ini dengan menyebutkan adanya ijmá $\bar{a}^{-}$ulama bahwa setiap tambahan atau hadiah yang disyaratkan oleh pihak yang memberikan pinjaman, maka tambahan itu adalah riba. ${ }^{45}$ Dalam gadai emas, ujrah (fee) untuk jasa penitipan penyimpanan, menurut aturan DSN-MUI, dibebankan kepada penggadai, yaitu nasabah.

Alasan ini sangat umum namun cukup kuat, tetapi untuk keadaan tertentu alasan yang demikian tidak dapat membenarkan pembebanan biaya penitipan kepada nasabah. Dalam konteks yang terakhir tidak dapat dibenarkan jika marbün (barang jaminan) dimanfaatkan oleh bank. Jika marbün dimanfaatkan oleh bank, maka biaya penitipan dan pemeliharaan dibebankan kepada bank bukan kepada nasabah sebagaimana hạaīth Nabi berikut.

$$
\begin{aligned}
& \text { عن أبي هريرة قال رسول الله صلى الله عليه وسلم الظهر يركب بنفقته اذا كان مرهونا, }
\end{aligned}
$$

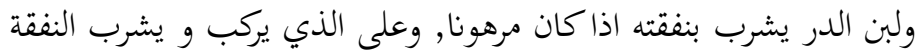

\footnotetext{
45 Ibn al-Mundhir, al-Ijmā‘ (Riyad: Dār Kunūz Eshbelia li al-Nashr wa al-Tawzī‘, 2006), 39.
} 
“Tunggangan yang digadaikan boleh dinaiki dengan menanggung biayanya, dan binatang ternak yang digadaikan dapat diperah susunya dengan menanggung biayanya. Bagi yang menggunakan kendaraan dan memerah susu wajib menyediakan penawaran dan pemeliharaan".

Dari beberapa alasan di atas, maka sistem gadai yang mencerminkan bybrid contract yang terkonstruk dari aturan DSN-MUI No. 26/DSN-MUI/III/2002 dan No. 92/DSN-MUI/IV/2014 merupakan sistem yang keberadaanya masih dipertanyakan sekalipun telah lama diimplementasikan dalam lembaga keuangan syariah. Walau bybrid contract gadai masih debatable, namun tuntutan kebutuhan transakasi kontemporer tidak dapat diabaikan. Inovasi akad ganda (bybrid contract) mutlak dibutuhkan.

Kebutuhan inovasi akad gadai yang meniscayakan kebolehan tentu sangat relevan dengan pendapat yang pertama bahwa pendapat yang pertama lebih kuat dan sesuai dengan perkembangan zaman dibanding dengan pendapat kedua. Pendapat yang pertama lebih kuat dan dapat memberikan solusi ligitatif terhadap persoalan bybrid contract gadai karena didukung oleh beberapa pertimbangan, yaitu; a) dalil yang digunakan dalam pendapat pertama memiliki status yang kuat dan kejelasan makna yang dikandungnya, b) kesesuaian dengan tujuan syariah, yaitu adanya kemudahan dalam muamalah, keringanan dalam beban, dan memberi peluang inovasi, dan c) relevan dengan tuntutan perkembangan zaman dan kebutuhan manusia terhadap transaksi keuangan modern. ${ }^{46}$

\section{Penutup}

Sistem gadai yang dikonstruk melalui aturan DSN-MUI merupakan suatu sistem yang menggabungkan bebarapa akad dalam transaksinya. Transaksi yang mengharuskan adanya jaminan sebenarnya untuk membangun kepercayaan bank dan tanggung jawab nasabah bahwa nasabah akan mengembalikan pinjamannya sesuai dengan akad. Akad yang dipakai adalah akad pinjaman, akad gadai dan akad sewa. Biaya sewa tempat didasarkan pada, misalnya, emas, kadar karat, berat dan jangka waktu gadainya. Biaya sewa dihitung untuk mengcover pembiayaan pemeliharaan, keamanan, dan asuransi. Jika pembiayaan dalam sistem gadai mengalami default, maka barang jaminan dijadikan kompensasi untuk pelunasan sisa tanggungan

46 al-'Imrānī, al- U qūed al-Māliyah, 74-75. 
nasabah. Aturan DSN-MUI No. 26/DSN-MUI/III/2002 dan No. 92/DSN-MUI/IV/2014 tentang gadai merefleksikan kombinasi tiga akad sekaligus. Kombinasi beberapa akad dalam produk gadai yang kemudian dikenal dengan bybrid contract bagaimanapun masih menuai kritik. Hadīth tentang larangan bay ' dan salaf, larangan mensyaratkan tambahan dalam hutang-piutang, dan larangan pembebanan biaya terhadap barang jaminan (kondisi tertertu) adalah beberapa hadìth yang mengritik dan tidak setuju dengan bybrid contract gadai dalam lembaga keuangan syariah. Namun, keberadaan bybrid contract gadai tetap tidak dapat diabaikan untuk merespons tuntutan transaksi kekinian dalam lembaga keuangan syariah dan dibenarkan selama tidak melampaui batas norma dan nilai syariah.

\section{Daftar Rujukan}

Agustianto, Inovasi Produk Perbankan Syariah dari Aspek Pengembangan Fikih Muamalah. Jakarta: IAEI, t.th.

Anas, Imām Mālik b. al-Mudawwanah al-Kubrā, Vol. 4. Beirut: Dār alȘādir, 1323.

Anshory, Abdul Gofur. Gadai Syariah di Indonesia: Konsep, Implementasi, dan Institusional. Yogyakarta: Gadjah Mada University Press, 2006.

Anwar, Syamsul. Hukum Perjanjian Syariah. Jakarta: Rajawali Press, 2007.

Bāshā, Muḥammad Qadrī. Murshid al-Hayrān ilā Márifat Aḅwāl al-Insān, Vol. 2. Kairo: Dār al-Furjān̄ī, 1983.

Dewan Syariah Nasional Majelis Ulama Indonesia, "Fatwa", dalam https://dsnmui.or.id/produk/fatwa/1, diakses pada 19 September 2017.

Hạmā̄, Nazīh. al-Uqūd al-Murakkabah fì al-Fiqh al-Islāmi. Damaskus: Dār al-Qalam, 2005.

Hanbal, Aḥmad b. Musnad al-Imām Aḥmad b. Hanbal. Kairo: Mu'assasat al-Risālah, 2009.

Hajjāi (al), Muslim b. Șaḥ̄ḥ Muslim, Vol. 5 (Beirut: Dār Iḥ̂ā’ al-Turāth al-'Arabī, t.th.

Ibn Qudāmah, al-Mughnì, Vol. 4. Kairo: Dār 'Ālam al-Kutub, 1997.

Ihtiar, Habib Wakidatul. "Analisis Fatwa Dewan Syariah Nasional Nomor: 92/DSN-MUI/IV/2014 tentang Pembiayaan yang Disertai Rahn”, An-Nisbab: Jurnal Ekonomi Syariah, Vol. 3, No. 1, Oktober, 2016. 
'Imrānī (al), 'Abd Allāh b. Muḥammad b. 'Abd Allāh. al-'Uqūd alMäliyah al-Murakkabah: Diräsah Fiqhìah Ta'silizyah wa Tatbiqiyah. Riyad: Dār Kunūz Eshbelia li al-Nashr wa al-Tawzî́, 2006.

Indonesia, Bank. Petunjuk Pelaksanaan Pembukaan Kantor Bank Syari'ah. Jakarta: Bank Indonesia, 1999.

Jawzī (al), Muhammad b. Abī Bakr Ayyūb al-Zar'ī Abū 'Abd Allāh b.

Qayyim. I'lām al-Muwaqqi'in. Riyāḍ: Dār Ibn al-Jawzī, 1423.

Jawzìyah (al), Ibn Qayyim. I'lam al-Muwaqqión 'an Rab al-'Alamin, Vol.

3. Kairo: Maktabat Ibn Taymìyah, t.th.

Ju'fí (al), Abū 'Abd Allāh Muḥammad b. Ismā'īl b. Ibrāhīm b.

Mughirah b. Bardizbah b. al-Bukhārī. Saḩị̄ al-Bukhār, Vol. 3.

Beirut: Dār al-Fikr, 1983.

Kholifah, Nadhifatul., Topowijono, dan Azizah, Devi Farah. "Analisis

System dan Prosedur Gadai Emas Syariah: Studi pada PT. Bank

Mega Syariah dan PT. Bank BNI Syariah Kantor Cabang

Malang", Jurnal Administrasi Bisnis, Vol. 5, No. 1, 2013.

Minawī (al), 'Abd al-Ra'ūf. al-Tawqîf 'alà Mubimmät al-Ta'arif, ed. M.

Riḍwān al-Dayah. Damaskus: Dār al-Fikr al-Mu'āṣir, 1410.

Mundhir (al), Ibn. al-Ijmāa : Riyad: Dār Kunūz Eshbelia li al-Nashr wa al-Tawzī', 2006.

Nawāwī (al), Abū Zakariyā Yahyā b. Sharaf. Rawdat al-Ṭälibìn, Vol. 3. Beirut: Dār al-Kutub, 1412.

Sanhūrī (al), 'Abd al-Razzāq. Mașädir al-Haqq fì al-Fiqh al-Islämi, Vol. 3.

Beirut: al-Majma' al-'Ilm al-'Arabī al-Islāmī, t.th.

Shawkānī (al), Muḥammad b. 'Alī b. Muḥammad. Fatḥ al-Qadìr, Vol. 1. Beirut: Dār al-Ma'rifah, 2013.

Sutedi, Adrian. Hukum Gadai Syariah. Bandung: Alfabeta, 2011.

Suyūṭi (al), Jalāl al-Dīn 'Abd al-Raḥmān. al-Ashbāh wa al-Nazaāì fì

Qawāid wa Furū' Fiqh al-Shäfi ryah. Beirut: Dār al-Kutub al'Ilmìyah, 1983.

Taymìyah, Ibn. Majmū‘ Fatāwà Ibn Taymìyah. Kairo: Dār al-Hadīth, 1995.

Tim Penyusun Kamus Pusat Bahasa Departemen Pendidikan Nasional, Kamus Besar Bahasa Indonesia, ed. 3. Jakarta: Balai Pustaka, 2007.

Zuhaylī (al), Wahbah. al-Figh al-Islämì wa Adillatuh, Vol. 4. Damaskus: Dār al-Fikr, 1989. 